\title{
法勝寺の伽藍形態とその特徵 \\ A HISTORICAL STUDY ON THE ARCHITECTURES AND THE PLANNING OF HOSSYOUJI TEMPLE
}

\author{
冨島義幸* \\ Yoshiyuki TOMISHIMA
}

\begin{abstract}
Representative of the late Heian Period, many attempts have been made to reproduce the planning of Hosshouji Temple. However, unexplained aspects regarding land, architecture and planning remain. Using various materials regarding planning, archeological studies, and historical records, I will reproduce the Hosshoji's plan, then compare the Hosshouji and Houjouji, examining their continuity, and originality.Both temples were very similar in terms of their pond, architecture and Buddhist imagery; particularly, their use of the Vairocana Buddha in the main hall of both temples. Nevertheless, Hosshouji emphasis of its main hall, independent of other structures, was its most unique characteristic.
\end{abstract}

Keywords: Hosshouji, Houjouji, Planning, Central Hall, Vairocana Buddha 法勝寺, 法成寺, 伽藍構成, 金堂, 大日如来

\section{はじめに}

承暦元年（1077）、白河天皇が建立した法勝寺は、院政期を 代表する寺院として、これまでに度々伽藍の復元が試みられた。

まず、福山敏男氏により「六勝寺の位置」において、法勝寺 の寺地と主要な建築の形式が論じられ!、最初の伽藍復元図が作 成されている2。また、林屋辰三郎氏により福山説の寺域北限を 広げる必要性が説かれ 3 、清水擴氏により伽藍と主要な建築の形 式が再考された 4 。近年、白河の条坊計画との関りから考古学を 中心に研究が進められ5、『甦る平安京』展に法勝寺伽藍の復元 模型が出品された ${ }^{6}$ 。しかし、法勝寺の寺域はいまだ定説が得ら れておらず、個々の建築についても検討すべき点が残されている。

拙稿「法勝寺の伽藍と建築」7では、法勝寺伽藍の創建から廃 絶までの沿革を検討し、先行する法成寺伽藍と共通する点が多々 見受けられることを指摘した。本稿では、まず法勝寺の伽藍と建 築について、これまでの復元諸説、考古学的成果に、文献史料か ら得られた新たな知見を合わせ、伽藍と建築を復元的に考察する。 次に、この復元的考察をもとに、法成寺伽藍と比較検討し、両者 の連続性、および法勝寺伽藍の独自性について論じる8。

\section{今日までの諸説}

福山氏により、白河における条坊道路の存在が指摘されて以来、 発掘調査が進められ、ここでの条坊計画が必ずしも旧京域の条坊 道路に則っていなかったことが明らかになりつつある。近年、最 初に法勝寺造営があり、その寺域が白河の条坊計画に影響した之 いう見方 ${ }^{9}$ が有力視され、法勝寺の寺域を明らかにすることは、 白河の都市計画を考えるうえでも重要な課題となった。

福山氏は、明治初期の地籍図をもとに、西限を現在の京都市動 物園西の公道あたり、東限を塔の中心から 50 丈程度の位置に設 定し、東西は 2 町よりやや広くなるとする。さらに、承保 3 年 (1076)の「法勝寺阿弥陀堂造立日時定記」 ${ }^{10}$ にのせる勘文の方位 · 寸法をもとに、押小路末の北端から二条大路末の南端までが約 40 丈、二条大路末の幅員が旧京域と同じ 17 丈であるとし、白河の 条坊道路は、京域の規格に則っていたとみなす。また、阿弥陀堂 の基壇の南端が押小路の北辺に当たることから、寺域の南限を押 小路末より南に設定し、冷泉小路末を二条大路末から 40 丈北に 設定して、ここを寺域の北限とする。

福山氏の伽藍復元図【図 1】“については、書物の性格もあっ て根拠は記されないが、前掲「六勝寺の位置」によって概ね知る ことができる。以下に、建築の配置に関わる要点を抜き出す。 1. 金堂の南庇が二条大路北辺の延長線上にあたる。 
2. 阿弥陀堂の基壇の南端が押小路の北辺にあたる。

3. 現曲尺で、金堂跡中心は塔跡中心の北 43 丈程、金堂跡、塔跡 ともに、公道（法勝寺西面道路）の東方 42 丈程にあたる。

4. 五大堂跡は金堂跡の西方、公道と二条通との辻の東北、薬師堂 は講堂の北、北斗堂、愛染堂は薬師堂の後方の左右にあたる。

5. 藤原氏の別業時代の釣殿御所は、法勝寺内の東方にある。

林屋辰三郎氏は、福山氏の復元のように、北限が怜泉小路末で あったならば、金堂背後の講堂・薬師堂・愛染堂・北斗堂の配置 が密になることから、北限を泠泉小路末より北に拡げる。

清水擴氏は、阿弥陀堂の南には析行 5 間以上の南廊が付属し ていたことから、福山説よりも寺地をさらに南に、林屋説に従い 北限を冷泉小路末より北に拡げる。清水氏は、

1. 金堂の裳階は吹き放ちで、左右の回廊は透廊の二階廊である。

2. 講堂南には、左右対称の孫庇がつく。

3. 阿弥陀堂の南には、 5 間以上の廊が付属する。

4. 五大堂は裳階付きである。

5. 法華堂には僧房が付属し、築垣をめぐらす。

6. 藤原氏別業の釣殿は、常行堂と御所の建設によって廃止された。 常行堂には東西の廊があり!2、回廊をめぐらして独立する。

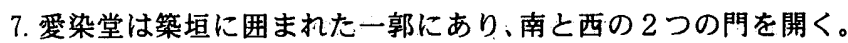
という新たな知見を加え、伽藍を復元している【図 2】 ${ }^{13}$ 。なお、 二条大路末の幅は狭く.その北辺は金堂南庇より南に設定される。

浜崎一志氏14は、発掘調查から想定される白河の条坊道路が、 必ずしも旧京域の条坊と一致しておらず、白河の条坊が法勝寺の 寺域に影響されたとみて、その北限を冷泉小路末と考える。法勝 寺の西で冷泉小路末の遺構（以下、冷泉末遺構 $\mathrm{A}$ とする）が旧京 域よりも北に検出され、遗構として南から $0.8 \mathrm{~m}$ の溝、 $2.4 \mathrm{~m}$ の築

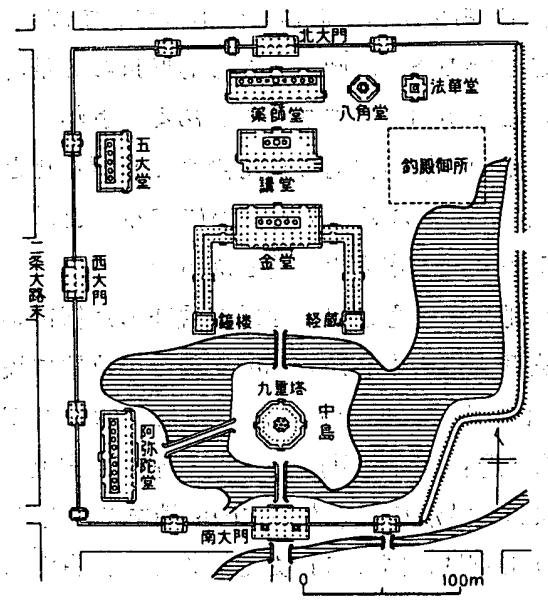

【図 1】法勝寺伽藍復元図（福山説） (福山敏男『平等院と中尊寺』去り)

\section{2 法勝寺の寺域とその造営}

\section{1 法勝寺の寺域}

これら諸説を整理すると、寺域の東限は塔中心から約 50 丈と する福山説が発掘の成果からも裏付けられ、西限も発掘調查によ り明らかになった。南限は押小路北辺より南に設定されるが、南 には白川が流れ、大きくは広がっていなかったとみてよかろう。

次に: 諸説で最も異なる寺域北限について考察しておく。『山 槐記』応保元年 (1161)7 月 7 日の条には、法勝寺への行幸経路は、 地、3m の犬行、2.6mの溝が報告され ${ }^{15}$ 、浜崎氏はこれを冷泉小 路末の南辺とみなす。この遺構の犬行、側溝の規模が多く、小路 とは考えられないこと、行幸経路として冷泉小路末が頻繁に用い られたことから、冷泉小路末が小路の規格よりも広かったと推測 する。また、福山説の寺域東限北延長上でも発掘により小路の存

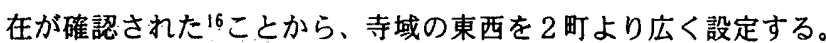

『生る平安京』展の復元模型【图 3】17における寺域・建築配 置は、京都市埋蔵文化財研究所の見解に基づく18。寺域の南北を 3 町とし、清水説とは常行堂・御所などにも大きな相異がある。 また、二条大路末の北辺は金堂南庇よりも北に設定されている。

上村和直氏 ${ }^{19}$ も寺域は東西 2 町以上、南北 2 町ないし 3 町とす る。発掘調查から得られた法勝寺西面道路の幅は、溝心々で 7 丈 6 尺とされている。

近年、冷泉小路末の冷泉遺構 $\mathrm{A}$ の位置より南に潬（以下、冷泉 遺構 $\mathrm{B}$ とする）が20、その東延長上にも溝（以下、冷泉遺構 C と する）発発見され 21 、冷泉遺構 $\mathrm{A}$ は冷泉末の北辺、冷泉遺構 B、 Cは南辺とみなされ、その規模は小路程度（約 4 丈）とされる。

また、堀内明博氏 ${ }^{22} に よ り$ 白河の発㨄調查に基づく新たな地割 復元が示された。法勝寺の寺域と関わる要点は以下の通りである。 1. 三条大路末は、金堂南庇より北に、その北辺のものと推定され る側漵跡が発見され、その道幅は約 18 丈に想定される。 2. 法勝寺の北限を冷泉小路末とする。

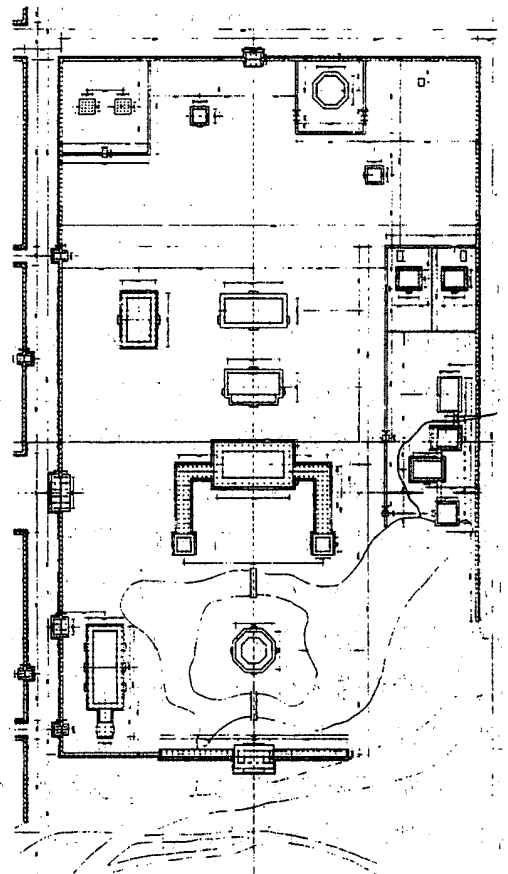

【図 3】同 (『靕る平安京』展模型) （京都市編『毝る平安京』展覧会目録より）
大炊御門東行、尊勝寺東大路南行、最勝寺北大路東行、法勝 寺西大路南行、入御阿弥陀堂西南築垣下、 とあり、大炊御門末を東に進み、尊勝寺東の「大路」を南に下り、 最勝寺北の「大路」を東へ進み、法勝寺西大路を南に下うた。法 勝寺への行幸では、この経路が普通に用いられたと考えられる。

『民経記』には、天福元年（1233）1月 ${ }^{23}$ の法勝寺修正会にさ いしての行幸経路について、

大炊御門菄坷原、瀬々仮橋使廳儲之如常、(中略) 大炊御門末猶 
東行、蓮華蔵院前令給過給、至東光寺前南行、冷泉末東行、法

勝寺北面大路、至法勝寺西大門大路南行、至西大門、

とある。大炊御門大路から鴨川を仮橋で渡り、大炊御門末を東に 進み、蓮華蔵院前を過ぎ、東光寺前を南に下り、冷泉末を東へと 進み、法勝寺の西面大路を南行して西大門へと到った。ここでは、 法勝寺北面は「冷泉末」、それは「大路」とされている。

先述のように、法勝寺西での発掘調査で、冷泉末とみられる 遺構 $\mathrm{A} \cdot \mathrm{B} \cdot \mathrm{C}$ が発見され、『民経記』の記事で「法勝寺北面大 路」と呼ばれる道は、冷泉末遺構に比定され、この延長上が法勝 寺の北限に当ると考えられる。

ただし、『民経記』で「法勝寺北面」が「大路」、『山槐記』 でも、尊勝寺東の道と冷泉末は「大路」とされる点は注意を要す る。発掘成果によれば、泠泉末は小路程度の規模、尊勝寺東にも 側溝が確認され、その道幅は約 4 丈とされる24。これら行幸で用 いる道は、実際には小路程度の規模でも「大路」と呼ばれていた。

\section{2 旧京域二条大路と法勝寺}

発掘調査に基づく『生る平安京』展復元模型、堀内説では、白 河二条大路末の北辺と金堂南庇は一致していない。これまで旧京 域二条大路と白河二条大路末の関係は考証されていないが、法勝 寺の造営、白河の条坊計画を考えるうえで重要な論点である。

前掲「法勝寺阿弥陀堂造立日時定記」の勘文には、

従六条坊門小路南㲽垣至于二条大路北辺垣、大路（略力）当金

北行六百廿三丈二尺、

〔本引用中（）内は、前掲福山「六勝寺の位置」による〕

とあり、金堂南庇は「二条大路北辺」にあたった。

また、同記同年 8 月 25 日の条には、

於朱雀門計午正景、庭前燎火揚煙、即於白河院御願寺、遥望火 基嫽火、定知午正立標、景正東西南北、

とあり、朱雀門で煙を焚いて法勝寺からこれを望み、東西南北の 方位を仰いだ。朱雀門、法勝寺における位置の詳細は明確にし得 ないが、朱雀門は二条大路の北辺に位置し、ここからも法勝寺造 営と旧京域二条大路の北辺との密接な関係がうかがえる。

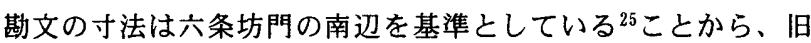
京域で計測したとみるべきである。勘文の「二条大路北辺」が旧 京域二条大路の北辺を指し、これが金堂南庇に当ったとみれば、 白河二条大路末の発掘成果と勘文の内容が矛盾するわけではない。 発掘成果によれば、二条大路末北辺は金堂南庇より北に位置し、 勘文通りに造営されたとすれば、鴨川を挟んで二条大路と二条大 路末の不一致、あるいは二条大路末の方位の振れが想定される ${ }^{26} 。$

\section{3 法勝寺の建築}

\section{1 八角九重塔}

永保 3 年 (1083) 10 月 1 日に供盖された八角九重塔 ${ }^{27}$ は、その規 模・特異な形式から、早くから注目されてきた ${ }^{28}$ 。建保元年 (1213) 再建塔の高さは 27 丈 ${ }^{29} 、$ かつて岡崎に残っていた九重塔の基壇 跡と考えられる円形土壇の直径は、15 間（約 $30 \mathrm{~m} ）$ あったとい $う^{30}$ 。1 13 世紀半ば頃までは瓦苜であったと考えられる31。 裳階 福山氏は伽藍復元図において、九重塔を一辺 1 間の母屋、 3 間の庇、3 間の裳階の平面とし、九重塔をはじめ金堂・阿弥陀 堂の裳階に建具を入れる。清水氏は九重塔を福山説と同じ平面形
式とするが、『門葉記』所収法勝寺金堂指図に裳階が描かれない ことから、裳階を吹き放ちとする。この指図で庇の柱間すべてに 建具、壁が入ることからも、金堂の裳階は吹き放ちと判断される。 さて、永保建立九重塔では文献史料から裳階は確認できないが、 九重塔再建供羡の『明月記』建保元年(1213)4月 26 日の条に、 除御塔裳層南北面中央各三間云々、外八面懸御策、其南箩醟力)間

為主上御在所、（中略）同東第一間為太上皇御所、

とある。裳階の南北面の中央三間を除き 8 面に御策を掛け、南面 裳階の西第 1 間は主上の御所、東第 1 間は太上皇の御所とされた。 ここで平安時代から鎌倉時代の法会における裳階の用途を概観 すると、鷹司本『年中行事絵巻』推定法勝寺大乗会の場面 ${ }^{32}$ では、 正面 11 間の裳階右側 4 間分に御策を掛け、左側には参列者が座 る様子が描かれる。これは左側では御策内部を見せるため、意図 的に描かなかったのであり、実際には裳階の中央 3 間を除いて御 策を掛け、御簾を掛けた柱間に参列者が座していたと考えられる。 法勝寺供養会では、金堂の裳階中央 3 間を除く左右に御策を掛 け、その最も中央寄りの柱間を天皇・上皇あるいは皇后の御座と した ${ }^{33}$ 。また、『経俊卿記』建長 5 年（1253）12 月 22 日の条に よれば、法勝寺阿弥陀堂の再建供養会で、裳階の正面中央 5 間を 除いて御笠を掛け、東面の御篻を掛けた最も中央奇り、すなわち 御笠を掛けなかった中央 5 間の両脇の柱間に天皇・上皇の御座を 設けた ${ }^{34}$ 。これが創建から鎌倉時代の法勝寺での建築供養会にお ける、裳階の一般的な使用形態であったとみられる。

九重塔の再建供養会でも同様であったと考えられ、裳階南北面 でも中央 3 間左右の柱間に御篻が掛けられ、南面の御䇥を掛けた 柱間を御所とすれば、前掲『明月記』の記述とも一致する。構造 上も、裳階の柱間数は、庇より左右 1 間ずつ多くなるのが自然で あり ${ }^{35}$ 、九重塔の裳階一辺は柱間 5 間であったと考えてよかろう。

御策は扉あるいは吹き放ちの柱間に掛けられるべきで、裳階中 央 3 間の左右柱間に御策が掛けられたとすれば、この柱間も扉あ るいは吹き放ちであったことになる。すべての柱間を扉とするこ とはないであろうから、裳階は吹き放ちであった可能性が高い。

\section{2 常行堂と御所}

常行堂 常行堂は中宮貿子追善のため、承徳 2 年（1085）8月 29 日に建立・供盖された。造営の資材を記した「法勝寺新堂并廊御 仏等用途勘文事」 ${ }^{36} に 「$ 御堂釘料」、「廊三宇釘料」とあり、常 行堂には廊 3 棟が附属し、瓦について「二万千六百三十六枚 御 堂料」、「三九千八百廿枚廊三宇料」とあり、常行堂・廊之 もに瓦莫であったと考えられる。 3 棟の廊は、東廊 ${ }^{37} \cdot$ 西廊 $^{38}$ ・ 北廊 ${ }^{39}$ であり、西廊には南妻に車寄があり、南北棟と考えられる。

寛治 5 年（1091）8月 7 日の地震を受けたとき、『扶桑略記』 に「法成寺（中略）、九重塔流星被震傾、（中略）常行堂壁并裳層 等、皆以震損」とある。この記事の「法成寺」は「法勝寺」の誤 りと判断され40、常行堂は裳階を備えていたと考えられる。また、 『中右記』寛治 7 年 (1093) 3 月 8 日の条に「於常行堂前庭人々有 上鞠之興」とあり、常行堂前には蹴鞠を行なう程度の庭があった。 常行堂御所の变遷 法勝寺供盖時、藤原氏累代の釣殿御所があり、 ここを御所とした。常行堂建立後は、釣殿に代って常行堂に付属 する廊が御所となった。東廊は 12 世紀半ばには「東寝殿」と呼 ばれ、南と東に弘庇が付き、常行堂と透渡廊でつながれていた 
御所はさらに:13 世紀半ばまでに整えられ、その姿を変えていた。

すなわち、阿弥陀堂の再建供養の準備について書かれた、『経 俊卿記』建長 5 年 (1253) 12 月 20 日の条には:

以常行堂御所為女院御方、(中略) 御所北子午颜為同女房台盤所、

(中略) 女院御方以東卯酉廊北面妻戸間為御車寄 所妻戸并東御 格子等出御几帳帷、北対西妻為女房出車々寄、同対西三ヶ間為 女院御方女房壸襧、第四間為同御方女官候所、仰修理職命儲棚、

又木工寮進唐欂、其以東四ヶ間為院御方女房壸蛹、以其東端二 ヶ間為二品喆蛹（中略）、以御堂西印酉廊為公卿座、同中門廊北 方屏内為殿上人候所（中欠）中門前引幔（中久）刻限所々供掌灯、 とある。まず、女院御方とされた常行堂御所の廊についてみると、 御所北の「子午廊」すなわち南北棟の廊を台盤所とした。東の「卯 酉廊」すなわち東西棟の廊の北面には妻戸があり、ここを車寄と し、その東には格子があった。御堂西の「卯酉廊」すなわち東西 棟の廊を公卿の座、御堂西の中門廊の北方を殿上人の座とし、こ の廊には中門廊・中門が付属してていた。次に北対があり、西妻は 女房の車寄、西側 3 間を女院の亜、第 4 間を女官の場、その東 4 間を女房の壳、東端 2 間は二品の壹としており、北対は東西 10 間以上になる。西に妻があったことから東西棟と考えられる。

また、同記同日の条に「以風㠊殿御所為御方 $\square \cdots \square$ 、（中略） 御湯殿具所口生储之、次御湯殿東為台盤所、(中略) 以風㯭殿北 為女官候所」とあり、風嘘殿・湯殿が付属していたと考えられる。

13 世紀半ばまでに整え.られた常行堂御所は、常行堂を中心と して御所・透渡廊・西廊・中門廊：中門・北対・風爈殿・湯殿な どからなり、その構成は、熾盛光堂を中心とする鎌倉後期の三条 白川房 ${ }^{42}$ に相通じるものと想定されよう。

\section{3 受染堂}

法勝寺愛染堂は、永保 3 年 (1083) 10 月 1 日、九重塔と合わせ て供養された。暦応 5 年（1342）3月 20 日の火災にさいして、 「中宮一品記」43では、火災を免れた建築の一つとして、「一円 堂、付門二宇築垣」と、円堂、築地、門2 棟をあげる。

『民経記』、天福元年（1233）6月21日の条には、愛染堂で修 された十壇愛染王護摩の様子が記され、「参円堂、入円堂東門」、 「入円堂東門、四脚門」とあり、東に四脚門があった。また、「十 壇円堂正面、東面」とあり、愛染堂は東を正面としていたと考え られる。受染堂内部では、「中壇母屋下敷半帖一枚為御室御座、

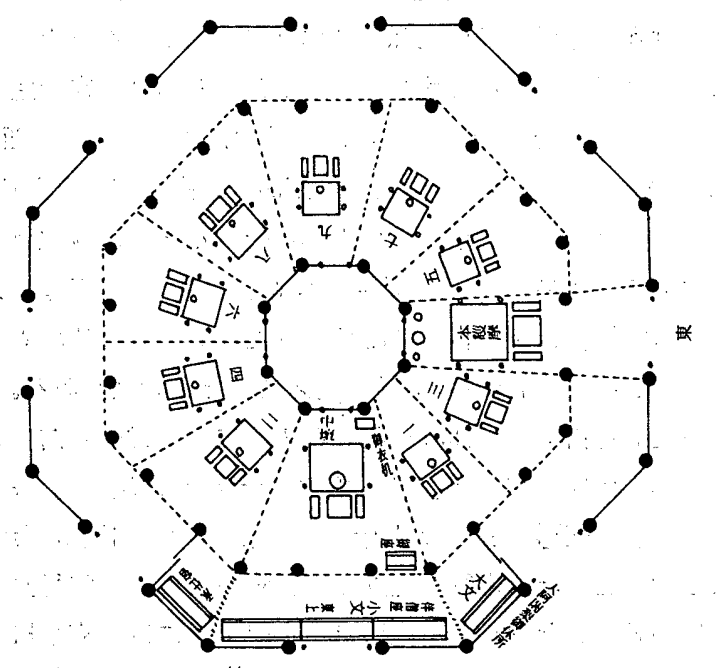

【图4】要染堂指図 ${ }^{44}$ (大日本古記録『民経記』所収指图より作成)
(中略）其間庇敷小文三枚、為伴僧八口座」と、母屋に御室御座、 庇に伴僧の座が設けられた。

同記には、護摩壇を配置した愛染堂の指図【図4】がのせら れ、この指図には三重に柱を回した平面形式で描かれる。中壇南 東に御座、その外に伴僧の座となる小文が描かれることから、愛 染堂の平面形式は母屋と庇からなり、中央の四方に乑を設けた部 分が厨子に相当することがわかる。

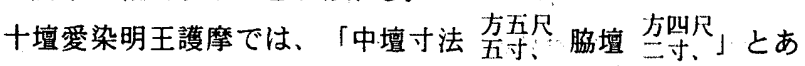
り、母屋に方 5 尺 5 寸の中壇 1 脚、方 4 尺 2 寸の脇壇 9 脚、寸法 不明の本護摩 1 脚を、厨子を取り囲むように配置していた。「自 御室被注遺之間、各触所課人云々、是道場連壇、其所狭之故也」 と、余裕があったわけでもないらしい。この点を勘案しても、愛 染堂は円堂としては大規模な建築であつたことがうかがえる。

\section{4 諸門}

前掲「中宮一品記」にあげられた建築から、寺地を開いてい た門を抜き出すと、南面は南大門と脇門 2 棟：西面は阿弥陀堂門 2 棟、西門（西大門）、五大堂門、北面は 3 棟である。東面は白 川の堤となり、門は開かれていなかった

『明月記』建保元年（1213）4月 26:日の条には、九重塔再建 供盖にさいしての門の守護武士について記される。守護武士が直 かれたのは、南面は大門・東脇門・西脇門、西面は大門・南門・ 北門、北面は大門・同小門・東胁門：西胘であった。

『経俊卿記』建長 5 年（1253）12月 22 日の条にも、阿弥陀堂 供盖当日、門守護武士を配する門として南大門・西大門・阿弥陀 堂門二宇・薬師堂門・北東端小門等があげられる。実際に守護武 士が配された門は、南大門・西二階門・・西北門 - 北門西脇・北門 とされる。12.月1日の条には、閉じておく門として南大門左右 脇門・五大堂門・法華堂間・薬師堂門・東小門をあげている。

以上から東面以外の各面の門をまとめると、南面は南大門と 東西脇門、西面は阿弥陀堂門 2 棟と西大門 - 西北門、北面は北大 門、同小門と東西脇門、北東端小門である。

五大堂門は「中宮一品記」で西面の門とされ、講堂の北西に 位置する五大堂近くに想定され、西面北の門と考えられる。

薬師堂門・法華堂門は、薬師堂・法華堂の位置から北面の門と

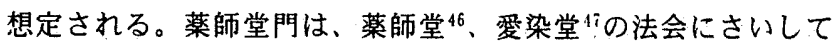
用いられた。薬師堂の位置から、その背後の北大門と推測される。 法華堂門は、法華堂に近い北面の東脇門に比定されよう。また、 『明月記』の記事からは、北大門には小門があり、東端にも小門 があったことがうかがえるが、詳細は明確にし得ない。

西大門 前掲『経俊卿記』にあらわれる西面の二階門は、西大門 と考えられるが、西大門は天皇・上皇あるいは法皇の法勝寺への 入場に用いられる重要な門であり、論を補っておくことにする。

『玉菜』承元 4 年（1210）１月９日の記事で、法勝寺修正への 行幸に随行した九条道家は「余以下前行、於門外騎馬、其路如例、 至於法勝寺東門、二階䅀、“条末也、下馬」と記す。この記録で、 二条大路末の「法勝寺東門」で下馬したとあるが、法勝寺の東面 に門はなく、「二条末」の「階門」と記されることから、この 二階門は西大門であったとみられる。また、』葉黄記』宝治元年 (1247)。8月 29 日の条には、上皇が御幸で、西面南門焼失、其 北門又少々焼損了、仍入御西面二階門」と、西面の「二階門」か 
ら入御したとし、この二階門も西大門を指すと考えられる。

以上、西大門を二階門とする記録は、いずれも 13 世紀のもの であるが、法勝寺では創建から暦応 5 年（1342）の焼失まで、西 大門再建の記事は見いだせない。したがって、西大門は創建当初 から二階門であったと考えられる。

\section{4 法勝寺伽藍の復元}

\section{1 建築の位膡関俰}

まず、これまでに論じられていない建築の位置関係を検討する。 鎮守総社・平㰌・反橋前揭「中宮一品記」には、焼失した建 築として金堂と回廊、鐘楼、経藏、講堂、阿弥陀堂、九重塔、鎮 守総社、南大門・阿弥陀堂門、平橋、南面および西面南方の築地 があげられる。延焼範囲は講堂から西南部であり、鎮守総社も伽 藍の西南にあったと考えられるが、具体的な位㯰は不明である48。 ここには焼失した平橋とともに、焼失を逃れた「前池反橋」 があげられる。『経俊卿記』建長 5 年 12 月 22 日の条には、阿弥 陀堂再建供養の当日、上皇・女院・公卿等が常行堂御所から阿弥 陀堂へ至る経路について「其路経常行堂西、金堂東、回廊東、并 御塔東南、渡平橋西折、傍池畔至阿弥陀堂御所」とある。つまり、 常行堂の西を経て、金堂・回廊の東を通り、金堂前の橋から中島 に渡り、九重塔の東から南へまわり、中島南の「平橋」を渡って、 阿弥陀堂南の御所へと至った。したがって、平橋は中島の南面に 架かり、反橋は中島の北面に架かっていたと考えられる。

講堂・法華堂・五大堂「承暦元年法勝寺供養記」 ${ }^{49}$ には、「講 堂北去十許丈、東西行引主殿寮班幕、西法華嘡西襄階年等六丈、」と、 講堂の北 10 丈程のところ東西に幕を引いたのであるが、この幕 の長さは西が法華堂に $5 、 6$ 丈及ばなかった。幕の東は明確でな いが、「裳階」は五大堂の裳階とみられ 50 、その「午」つまり五 大堂裳階の南面、および法華堂は、講堂の背後 10 丈あたりに位

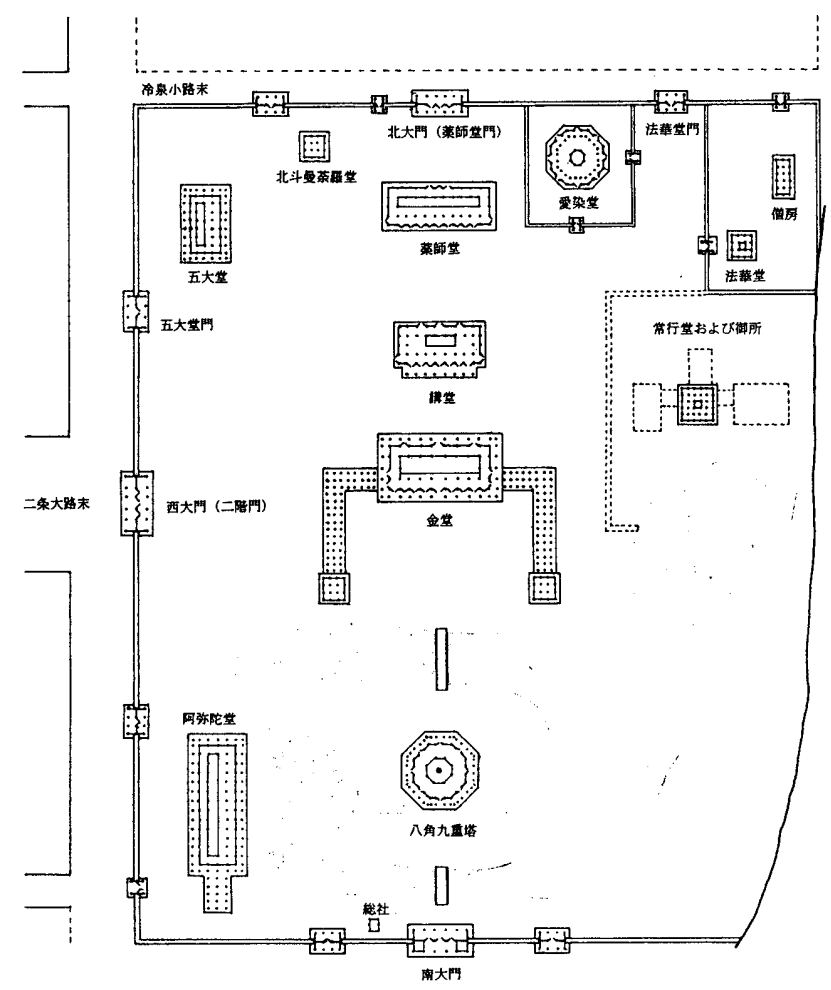

【図 5】法勝寺伽藍復元図
置していたと考えられる。寺域の北辺が金堂南庇からおよそ 50 丈の位置に想定されること、講堂が金堂の北に位置していたこと から、五大堂・法華堂は寺域北辺部に建っていたと考えられる。

なお、『兵範記』仁平 2 年(1152)8 月 16 日の条には、講堂で の鳥羽法皇五十算賀の指図がのせられるが、この指図には講堂の 前に金堂の一部が描かれ、両者の位置関係を知ることができる。 阿弥陀堂之前池『経俊卿記』建長 5 年（1253）12月 22 日の 条に、阿弥陀堂再建供養での鋪設について、

東階一丈五尺東西差退、立蓋高座各一脚、其中央立礼盤二脚、其東池

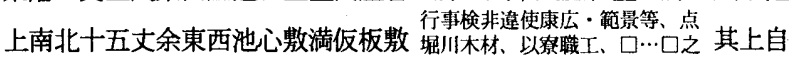
蓋高座去二丈余、立舞台 方三丈三尺幡借渡之

とあり、阿弥陀堂東の池には南北 15 丈の仮板が敷かれたことが わかる。福山説では阿弥陀堂前から中島に橋を架けるが、板を敷 き渡した以上、この橋はなかったとみられる。

この供養会では、阿弥陀堂基壇東面から東 1 丈 5 尺に高座・礼 盤を置き、その東は、池の仮板敷となり、舞台以下の鋪設がなさ れた。また、舞台は高座から東 2 丈程の位置にあったので、仮板 敷は阿弥陀堂基壇東端から高座等の寸法を除いて、1丈 5 尺丈か ら 3 丈 5 尺の位置まで迫っていた。したがって池の汀線も、阿弥 陀堂基壇かなりの近くまで迫っていたとみられるう。

この他、小塔院、正庁宝蔵 ${ }^{2}$ 、大湯屋 ${ }^{53}$ があったが、その形式、 位置は明らかにし得ない。

\section{2 伽藍の復元}

寺域については、二条大路末と金堂の位置関係、二条大路末の 道幅は、発掘調査に基づく堀内説に従う。また、寺域の北限は、 考古学的成果・文献史料からの考察に基づき、冷泉小路末に比定 されている発掘遺構の位置とする。金堂の位置・規模・形態は発 掘遺構に基づき、回廊の柱間数、鐘楼・経蔵の形式は福山説に従 う。講堂・薬師堂・五大堂・阿弥陀堂・常行堂・鎮守総社の形態、 愛染堂・法華堂を築垣に囲まれ独立した一郭とすることは清水説 に従う。常行堂の一郭を囲む装置は、清水説以上に明確にし得な い。これら以外の建築の形態、位置関倸は、本稿の考察に基づく。 以上から、白河天皇（上皇・法皇）により完成された法勝寺伽 藍を復元したのが【図 5】である。

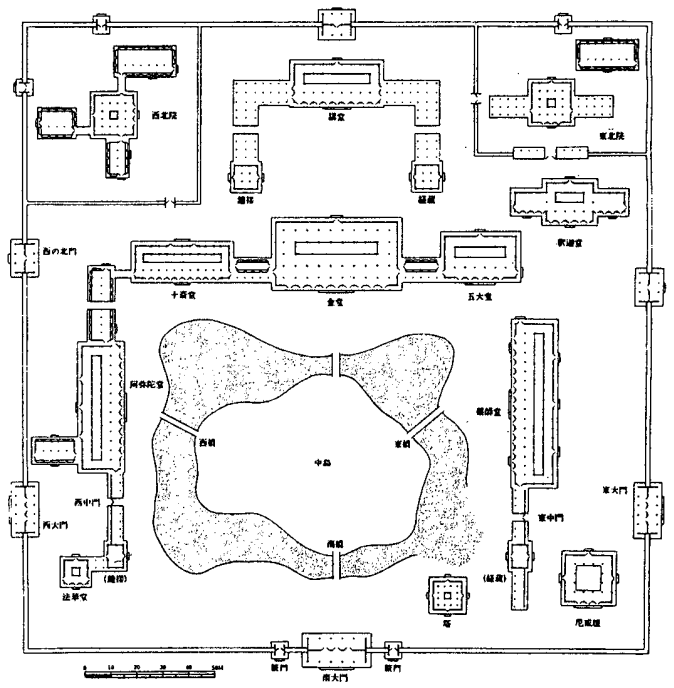

【図 6】法成寺伽藍復元図

（清水撞『平安時代仏教建策史の研究』より） 
5 法勝寺伽藍と法成寺伽藍

ここでは、法勝寺・法成寺の伽藍復元図をもとに、法勝寺が法 成寺から何を継承し、如何なる進展をみせたか、とくに金堂とそ
の中尊に注目して述べる。【図6】は、天喜 6 年(1058).の焼失以 前に完成された法成寺伽藍である゙4。この検討にあたっては、法 勝寺伽藍を九重塔建立以前と以後に区別しておく必要がある。

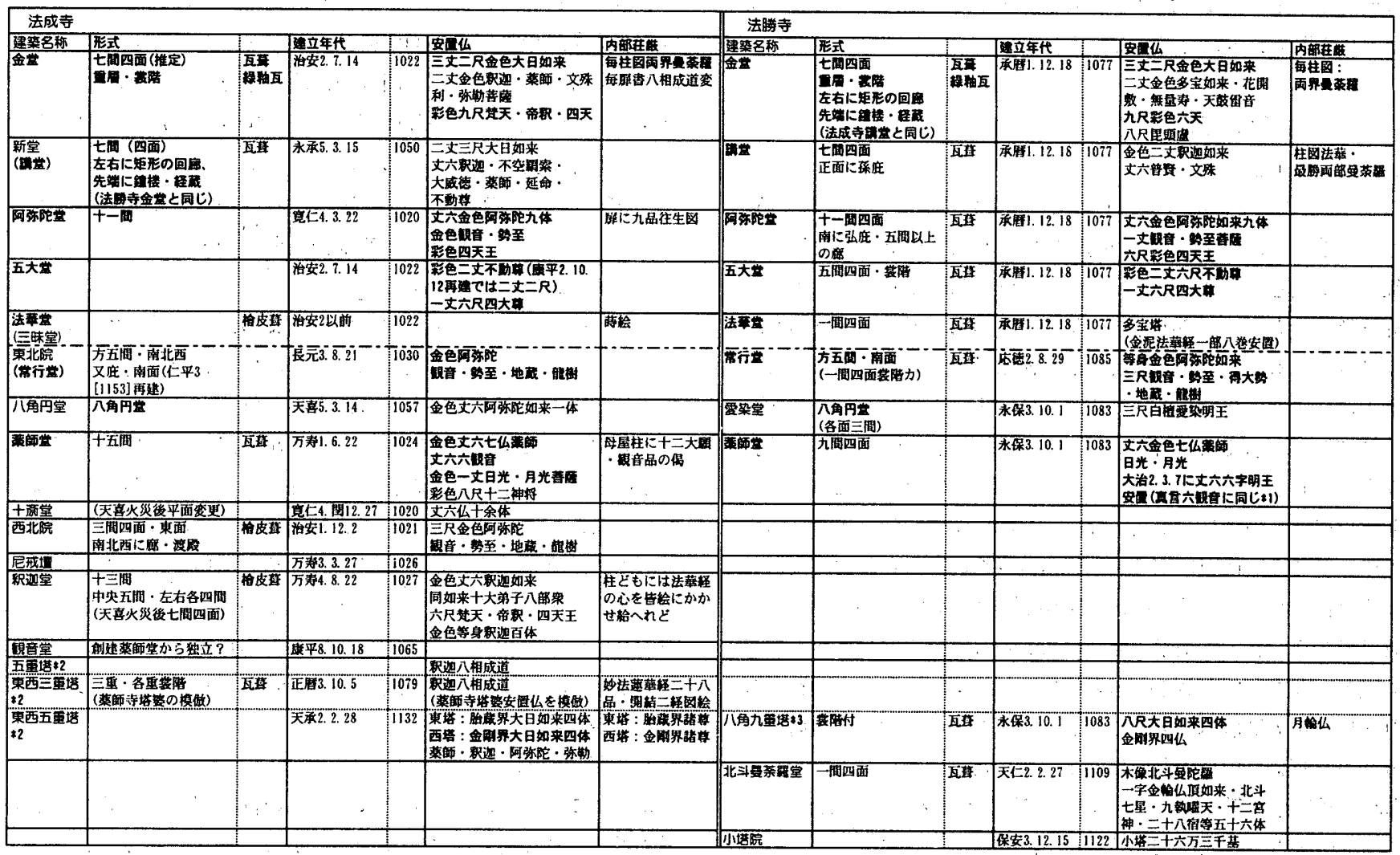

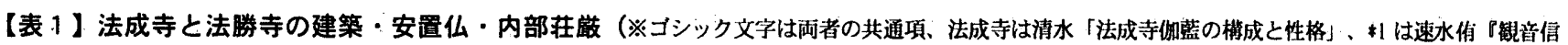

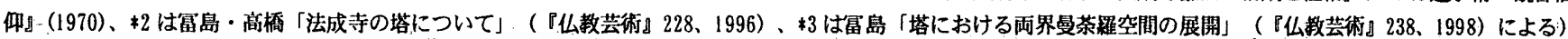

\section{1 九重塔建立以前の法勝寺伽藍}

法勝寺創建時の建築は、金堂・講堂・阿弥陀堂・五大堂 - 法華 堂であるが、これらはすべて法成寺伽藍に渞い、規模・形態、安 置仏の多くが共通する（【表1】を参照）。中島を持つ園池を中 心に、北に金堂、西に阿弥陀堂を配する構成も法成寺と共通する。

法成寺伽藍は、その形態についていえば、平等院など後の浄土 教伽藍の発端となる寺院と位㯰付けらる55。しかし、池を取り巻 く建築には、大日如来を安置する金堂、五大明王を安置する五大 堂といった、明らかに净土教とは異なった信仰に基づく建築も含 まれ、信仰においては净土教のみに基づいているわけではない。

法勝寺伽藍も、『栄華物語』巻第三十九「布引の滝」 ${ }^{56} に 、$

御堂のけ高うものものしきが、新しう赤く㓌り立てられたるに、

青やかに見え渡されたる御堂の飾りなど、極楽にたがふ所なげり。 とあり、伽藍・建築の形態においては、現世に極楽浄土を造立し ようとした净土教伽藍とみなせよう。しかし、伽藍の最も中心と なる金堂は胎蔵界五仏を安置し、密教の両界曼茶羅のうち胎蔵界 曼茶羅に基づき、信仰上は浄士教のみに基づくわけではない。

\section{2 金堂の形態と中孪・内部荘览}

法勝寺金堂は文献史料 ${ }^{57} \cdot$ 発掘調查 ${ }^{58}$ から、形式・規模が概ね 明らかにされている。七間四面、裳階を備えた重層建築で、東西 に各 20 間の回廊を備え、回廊は南辺で数えて東西に 5 間伸びた ところで南に折れ、先端に鐘楼・経蔵を置く。回廊・鐘楼・経蔵 の構成は、先行する法成寺講堂と共通する。
法勝寺金堂には緑釉瓦を用いていたが、法成寺金堂でも同じく 緑釉瓦を用いていた。法勝寺金堂では、法成寺金堂と全く同じ規 模の大日如来（毘盧遮那如来）を中尊とする。脇侍四仏の種類は 両者で異なるが、規模は全く同じで、六天は規模も同じである。 母屋柱に両界曼茶羅諸尊を描くことも両者で共通している。

とくに金堂の胎藏界大日.如来は「花葉安㯰百体积迦」99 と、「花 葉」すなわち蓮華座の葉に百体の釈迦を安置する特異な仏であっ た。法成寺金堂の大日如来も「坐中央百葉蓮華座、荘蕨微妙也、 $一>$ 蓮華葉上、百体积迦又現」 ${ }^{60}$ と、百葉の蓮華座に座し、蓮華 の葉に百体の积迦を現し、同じ思想に基づくと考えられる61。こ のように法勝寺金堂は、法成寺金堂の影響を強く受けていた。

\section{結 一法勝寺伽藍の特徽一}

法成寺では、金堂の左右に十斎堂・五大堂が回廊で取り付き、 さらに阿弥陀堂・薬師堂が一体となって園池を取り囲む。ところ が法勝寺では、阿弥陀堂・五大堂は金堂から切り離されて伽藍の 隅に建ち、後に建立される薬師堂・愛染堂・北斗曼茶羅堂も伽藍 の周辺部に置かれた。金堂は、珈藍のまさに中心に独立して建つ。 法勝寺の伽藍構成は、金堂を独立させ、伽藍のなかで強調する ことを意図したものと考えられる。回廊・鐘楼・経蔵にようて強 調される左右対称の形態も、金堂の独立性を際立たせることにな つた。つまり創建当初の法勝寺伽藍は、園池・建築・安置仏など、 伽藍を構成する要素の多くを法成寺に求めながら、伽藍構成では 
金堂を独立させ、その中心性を強調した点が最大の特徵といえる。 また、旧京域と法勝寺との関係も見落してはならない。白河で はまず法勝寺が造営され、その寺域が条坊計画に影響した。法勝 寺の造営は旧京域、とくに二条大路および朱雀門と密接な関係が あったことは重要と考えられる。発掘成果によれば、金堂は二条 大路末の突き当たりに位置する。鴨川と挟んで二条大路と二条大 路末に多少の不一致が想定されるが、大内裏の朱雀門前、平安京 最大の東西道路である二条大路の延長上に、二階門一西大門一を 開き、大極殿に匹敵する規模の重閣建築一金堂一を据えた法勝寺 は、朱雀門からの景観でも際立つ存在であったと考えられる。

天喜 6 年 (1058)に焼亡した大極殿は、14 年も後の延久 4 年 (1072)、白河天皇踐袮の年に再建され、その即位式は大極殿で行 われた。平安末期以降の朝堂院の衰退が指摘されるが62、白河天 皇即位からしばらくは、大極殿・朱雀門をふくむ大内裏は、天皇 権力の象徵としての意義を保っていたと考えられる。

白河天皇が御願寺として天皇在位中になしとげた法勝寺および 九重塔の建立は、藤原摄関家権力に対する白河天皇権力の優越を 誇示することにあったと考えられる ${ }^{63}$ 。その一方で法勝寺の造営 は、洛東の地が「京白河」として洛中と並び称される都市へ発展 する契機と位置付けられる。新たな都市の構築において、白河天 皇権力を象徵する法勝寺は、白河の中核として、同じく天皇権力 を象徵する大内裏との密接な関係のもとに造営されたと考えられ る。創建当初の金堂はまさにその象徵であり、後の八角九重塔建 立もこの構想の延長上にあったといえよう。

【付記】本稿の執筆にあたっては：白河での発掘成果について堀内明 博氏から多くの御教示をいただいた。ここに記して謝意をあらわしたい。

\section{【註】}

福山敏男『日本建築史研究』（墨水書房、1968）。

2 褔山敏男『平等院と中尊寺』（『日本の美術 9 』平凡社、1964)。

${ }^{3}$ 林屋辰三郎「法勝寺の創建」（同『古典文化の創造』東京大学出版会、1964）

${ }^{4}$ 清水摭「六勝寺伽藍の構成之性格」(『建策史学』5号、1998.10)、同『平 安時代仏教建築史の研究』（中央公論美術出版、1992）に再録。

“浜崎一志「白河の条坊地割」（京都大学埋藏文化財研究センター『京都大学地 蔵文化財調査報告』 N、1991）、上村和直「院政之白河」（古代学協会·古代 学研究所編『平安京提要』角川書店、1994）、堀内明博「権門の都加ら洛中辺土 の京へ一武家地と町の展開にむけて」（網野善彦・石井進編『中世の風景と読 む5』新人物往来社、1995)

京都市編『平安建都 1200 年記念展覧会目録 脜る平安京』（1994）。

?畕島義幸・高橋康夫「法勝寺の伽藍と建筑」（『建築史学』 26 号、1996.7)。 8 山岸常人「法勝寺の評価をめぐって」（『日本史研究』426 号、1998. 2) にお いて、前揭註 4 清水論文、前揭註 7 目島・高橋諭文で、法勝寺の性格を伽藍・建 築の形捻のみから考察している点が批判されている。本稿では㑬藍・建筑形態か ら読み取れる性格を論じることを目的とし、より広い視野から考察は別稿で行う。 9 前掲註 4 浜崎論文。

10 藤田経世編『校刊美術史料』寺院編中（中央公論美術出版、1975）所収「諸 寺供盖類記」

11 前揭註 2 褔山著書。

12 前掲社 4 清水論文で復元図に北対を置くが、本文中では北対にふれれられない。

13 前掲註 4 清水論文

14 前揭註 5 浜崦論文。

15 暒川敏夫 ·渡辺和子「尊勝寺推定地第 巩次発据調查概要」（京都市文化観光 局文化財保護課『京都市埋藏文化財年次報告 1976-II』、1977)。

16 京都市埋蔵文化財研究所『白河街区跡RITZ OKAZAKI 新策工事に伴亏発猢調査

終了報告書』（1988）。

${ }^{17}$ 前揭註 6 『毝る平安京』展覽会目録。

18 前掲註 6 『速る平安京』展覧会目録所收の高橋康夫「法勝寺」解説による。

19 前揭註 5 上村論文。

20 尾藤德行・吉村正親「最勝寺跡・㓮崎遗跡」（京都市埋藏文化財研究所『平 成 6 年度 京都市内遺跡立会調查概報』、1995)。

21 䏱内朋博・竜子「白河街区跡・風崎遭跡」（京都市埋藏文化財研究所『平成

8 年度 京都市内遺跡立会調查概報』、1997)。

22 前提註 5 垱内論文。

${ }^{23}$ この部分は日付が欠落しているが、他の史料から1月12日と推定される。

24 堀内明博「白河街区跡」(京都市埋藏文化財研究所『平成 7 年度 京都市埋
藏文化財調查概要』、1997)

25 同勘文では、阿弥陀堂基㙩南端あたる「二条南小路!、すなわち押小路の北 辺から六条坊門南辺の間を計測しており、六条坊門南辺が基準となっていた。

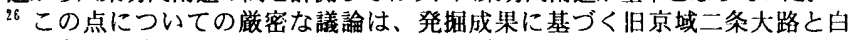
河二条大路末の位置関係の検証を待たねばならない。

27 『朝野群載』巻第 2 所収「法勝寺御塔供羕呪渎文〕。

${ }^{28}$ 中郷敏夫「法勝寺八角九重塔雑攻」（『史跡と美術』51、1935）、西田直二 郎「法勝寺遗址」（同『京都史跡の研究』吉川弘文館、196i）。

${ }^{29}$ 暦応 3 年 $(1340)$ の写本である「院家雑々跡文」（『大日本史料』所収）。

30 前掍註 27 西田論文。

31 前揭註 7 冨島・高橋譮文。

${ }^{32}$ 福山敏男「年中行事絵巻の推定法勝寺大乗会図」(前掲註 1『日本建築史研究』)。

33 前掲註 10 「諸寺供盖類部」所收「承暦元年十二月法勝寺供盖記」、「承暦元

年法勝寺供養記」。なお、法勝寺供養会の形態は、井上充夫『日本上代建築にお ける空間の研究』（私家版、1961）で考証されている。

${ }^{34}$ 阿弥陀堂は十一間四面裳階付きであるから、その西面の柱間は 15 間となる。 同記に「裳層東南北除五ヶ間之外〈東南北裳層簧子四面打數满弘筵 引用部分

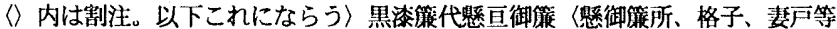
暫撤之〉」とあり、左右の 5 間ずつに御篻を掛けたことになる。天皇の御座は「北 第五間」、上皇の御座は「南第五間」に設けられたので、御䈨の掛けられた部分 のうち、最も中央寄りであったことになる。

35 庇の柱から裳階の柱に慗ぎ虹梁を架けるとき、慗ぎ虹梁を柱筋に莗淔に出す と、左右に柱を 1 本ずつ入れ、柱間を 1 間ずつ増やさない限り、裳階两脇の柱間 は、庇と裳階の梁行寸泫分だけ広くなる。海住山寺五重塔は、裳階の中央 2 本の 柱を抜き、一辺を 3 間としているが、この五重塔は初重の身舎一辺が 10 尺に满 たない小規模な塔であり、柱の省略も可能であったと考えられる。しかし、大規 模な法勝寺八角九重塔では、裳階の柱は省略できなかったであろう。

36 『平安遗文』1228 号。

37 名右范』承徳 2 年（1085）9月 22 日の条に、「於常行堂従今日寡時三ヶ日 間有不断念仏也、又其東於御所廊有御経供美」とある。

38 『中右記』康和 4 年 (1102) 2 月 26 日の条に、「寄御奥於常行堂西廊南妻、 西廊引幔、(中略) 以常行堂東廊為内御所」、同記同年7月20日の条に、「答 御興於常行堂西廊南妻、敷笘道也、法王兼御座此御所」とある。

39 殿暦』天永 3 年 (1112) 11 月 25 日の条に、「今日於法勝寺奉為上皇余有御 賀事、余居奉後下缩所、常行堂北廊」とある。

40 前掍註 7 冨島・高橋論文。

${ }^{41}$ 前掲註 4 清水淪文。

42 福山敏男「最勝吗天王院とその障子絵」（同『日本建築史の研究』、1953）。

43 『大日本史料』所収。

${ }^{44}$ 杉山信三氏の御教示による。

45 前掍註 1 福山論文。

46 『門葉記』延店元年（1239）12 月 23 日の条。法勝寺薬師堂で、尊勝寺で修す るべき潅頂を行った記録をのせ、腰奥で蒋師堂の門から入り、慗師堂に至った。 47 『民経記』天福元年 (1233) 6月21日の条。薬師堂門を程て罍染堂に至つた。 48 鎮守社は、例えば東寺では、南大門のすぐ西北に鎮守八幡宮が置かれている。

${ }^{49}$ 前掲註 10 「諸寺供盖類記」所収。

50 前掲註 4 清水論文。

1 『作庭記』には、翡殿の前、池の汀線までの距離を記すなか、「堂社なとに は四五丈も難あるへからす」と、4、5 丈でも善し支えないとするが、法勝寺阿 弥陀堂と前池の関係はこの記述とよく一致する。清口正人氏の御教示による。

52 『百鍊抄』安貞 2 年(1228) 9 月 29 日の条。

53 『兵範記』仁平 2 年(1152)8 月 16 日の条

${ }^{54}$ 清水擦「法成寺伽藍の構成と性格」（前掲註 4 清水著書所収）所収の後元図。 法成寺伽藍の汾革は、杉山信三「「藤原氏の氏寺とその院家」（同『院家建築の 研究』吉川弘文館、1981）においても群細に㭲討されている。天喜火災後の再建 では承暦 3 年(1079)に東西塔が建立、承德元年(1097)の講堂再建で中門・回郎が 加わり、积迦堂の規模が変るなど、創建から若干変化した点も証められる。しか し、本稿で問題とする伽藍構成については、大きな変更はなかったとみられる。 康平 8 年(1065) 観音堂が供敾されたが、同時に薬師堂も供盖されている。12 世紀初頭の尊勝寺では、観音堂亡蒋師堂が独立して建つ(前掦註 4 清水論文) が、 法成寺では創建薬師堂に七仟薬師と六锶音をあわせて安置し、天喜火災後の再建 は過渡期と位犆付けられる。再建では、創建時と同様に一楝に安圆しており、再 建における菂師堂と観音堂はこれを継承したもので、七仏犀師部分を莸師堂、六 锶音部分を観音堂と呼んだか、あるいは尊勝寺のように二者を独立させた可能性 が考えられる。こうした六観音の独立の背景には、六観音法の発達が考えられる。 55 前揭註 54 清水論文。

${ }^{56}$ 日本古典文学大系『栄花物語』（岩波書店、1955）による。

${ }^{57}$ 前掍註 10 「諸寺供養類記」の法勝寺供養記など。

${ }^{58}$ 杉山信三・棍川敏夫「法勝寺金堂跡発㧩調查概要」（京都市文化観光局文化

剘保護課『法勝寺跡 京都市埋蔵文化財年次報告』、1974）。

${ }^{59}$ 前掲註 10 「諸寺供養類記」所収「承暦元年十二月法勝寺供善記」。

60 前掲註 10 「諸寺供益類記」所収〔不知記」。

61 法成寺金堂、法勝寺金堂の中尊大日如来の蓮華座に現わされた秎迦は、『梵 網経』に基づく千釈迦と考えられる。この点は、別稿で詳しく論じることにする。 62 溝口正人「中世即位式の空間構造」(1野邦一・片林篤編『建築史の想像力 学芸出版社、1996)

${ }^{63}$ 前掲註 7 富島・高橋論文。

(1998年 5 月 8 日原稿受理，1998年 9 月 8 日採用決定） 